\title{
Application of electrical geophysics to the release of water resources, case of Ain Leuh (Morocco)
}

\author{
A. Zitouni ${ }^{1 *}, A$. Boukdir ${ }^{1}, H$. El Fjiji ${ }^{2}, W$. Baite $^{1}$, V.R. Ekouele Mbaki ${ }^{1}, H$. Ben Said ${ }^{1}, Z$. \\ Echakraoui $^{1}, A$. Elissami $^{3}$ et M.R. El Maslouhi ${ }^{4}$ \\ ${ }^{1}$ Laboratory of Industrial engineering, Faculty of Sciences and Technics, Sultan Moulay Slimane \\ University, Beni Mellal, Morocco. \\ ${ }^{2}$ Méditerranée Travaux Etudes Et Conseils D’ingénierie (MEDITEC-IN), Beni Mellal, Morocco. \\ ${ }^{3}$ National Office of Electricity and Drinking Water (ONEE), Rabat, Morocco. \\ ${ }^{4}$ Oum Er-Rbia Hydraulic Basin Agency (ABHOER), Beni Mellal, Morocco.
}

\begin{abstract}
Being seen needs in increasing waters in our contry for fine domestics, manufactures and agricultural, the prospecting of subterranean waters by geologic and hydrogeologic classic method remains inaplicable in the cases of the regions where one does not arrange drillings or polls (soundings) of gratitude (recongnition) in very sufficient (self-important) number.

In that case of figure, the method of prospecting geophysics such as the method of nuclear magnetic resonance (NMR) and the method of the geophysics radar are usually used most usually because they showed, worldwide, results very desive in the projects of prospecting and evaluation of the resources in subterranean waters.

In the present work, which concerns only the methodology of the electric resistivity, we treat the adopted methodological approach and the study of the case of application in the tray of Ajdir Ain Leuh.
\end{abstract}

Key words: electric resistivity, methodology, hydrogeology, prospection, ressources in subterranean waters, tray of Ajdir Ain Leuh.

\section{Introduction}

The mountains are generally called "water towers of the planet". This qualifier is based on the precipitation potential associated with terrain and snow-ice retention. The barrier effect (according to moist air masses) and the altitudinal effect result in more abundant precipitation and snow-ice storage (depending on altitude) of precipitation; storage returned to surface and underground flows during the summer seasons. The mountain water appears in this scheme as an abundant and inexhaustible resource renewing from one year to another [14].

However, access to drinking water, especially in mountainous areas, is a major factor in economic development, and in improving the standard of living of populations and their stabilization in rural areas.

This study is part of securing the drinking water supply for the mountainous area at the Ajdir Ain Leuh plateau.

It is in this context, we present in this work the contributions of the application of the method of electrical soundings to the recognition of different aquifer formations. This will make it possible to define underground water potential and quantify the groundwater table in order to decide on the most appropriate option for mobilizing groundwater resources,

*Corresponding Author: abdelhamidgat@gmail.com 
taking into account productivities, quality as well as the constraints linked to the influence of water mobilization on water resources already exploited, including sources [5].

\section{Description of the study area}

\subsection{Geographical setting}

The Ain Leuh and Mrirt zones are located southeast of the Sebou basin between Ifrane and Khénifra on the main road $n^{\circ} 24$ (Fig. 1), they belong to the Middle Atlas tabular plateau, framed on the north by the South-West corridor-Rifain, to the south by the High Atlas and the valley of Upper Moulouya, to the east by the valley of the Middle Moulouya and to the west by the Moroccan Meseta.

Morphologically, the Ain Leuh-Mrirt area is characterized by a tabular structure, more faulted than folded, by a monotonous relief implying the Middle Atlas pleated with accentuated folds, high mountains and deep marly depressions. It is a monotonous lithology of weakly folded liasic limestones which is responsible for this platitude.

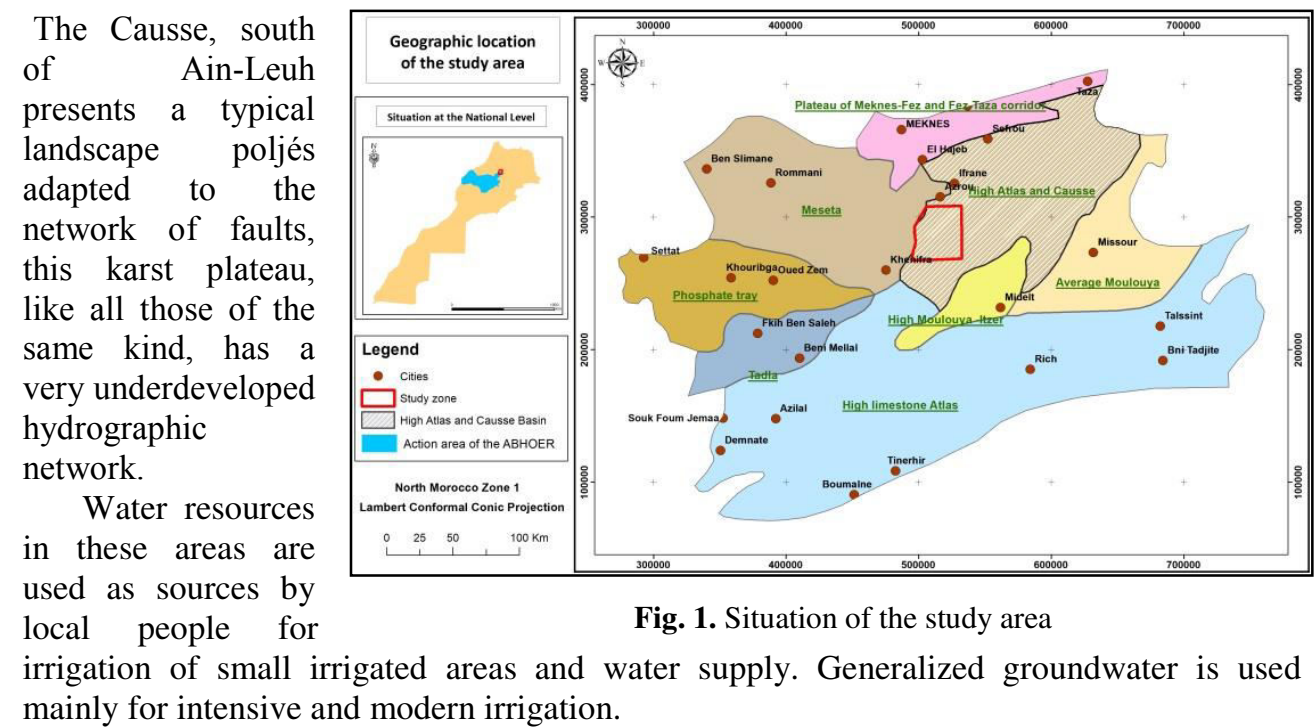

\subsection{Climate context}

The climate prevailing in the Middle Atlas is Mediterranean Type Mountain; it is characterized by a wet and cold climate. This particular climate of the Middle Atlas is due mainly to its altitudinal position, its geographical situation and its exposure to marine influences [15]. The clouds coming from the west give abundant precipitations (rain, snow) in contact with the Middle Atlas. The natural barrier that forms the chain Atlasique creates a dissymmetry on the climatic plan: the Atlantic facade exposed to the winds coming from the NW is more watered; as for the SE facade which is subject to the influence of the Saharan climate [16].

In general, the climate of the causses is a Mediterranean climate of mountain, cool and wet; it snows in abundance on the heights and the quantities of rain exceed $1100 \mathrm{~mm} /$ year in Ifrane, but as we decent towards the south, the rains become less abundant.

\subsection{Hydrogeological context}

The Moroccan average atlasic causse has been the subject of several geological studies. Il est constitué de plateaux d'altitude comprise entre 1000 et $2200 \mathrm{~m}$, constitués par la prédominance de formations carbonatées du Lias inférieur et moyen, découpées en blocs $\mathrm{t}$ 
consists of plateaus of altitude between 1000 and $2200 \mathrm{~m}$, consisting of the predominance of carbonate formations of the lower and middle Lias, cut into fault blocks along several northeast-trending faults (Fig. 4). The Causse is limited to the west by the primary lands of Wadi Beht (Moroccan primary Meseta) and those of Tazzeka to the northwest. To the north, the limit is determined by Tertiary and Quaternary overburden in the South Rifain Corridor [17].

The dominant facies consists of dolomite and limestone and liasic, locally covered quaternary basaltic flows, resulting from recent volcanic activities (Figure 4). The dolomitic layers of the lower Lias lie in probable concordance on the Triassic (Colo, 1961). The middle Lias is characterized by limestones of different colors, in fact, the northern part of the Causse is essentially Dolomitic, that of the southern section is essentially limestone.

The Atlas Mean Causse includes two main aquifers of unequal interest; these are the aquifer of the quaternary basalts (Dolerites) and that of the dolomitic limestones of the Lias.

\subsubsection{Basaltic aquifer}

The basaltic aquifer of the Middle Atlas Causa can be subdivided into two hydrogeological sub-basins: Tigrigra (area of approximately $546 \mathrm{~km}^{2}$ ) and Timahdite (area of approximately $435 \mathrm{~km}^{2}$ ). These two compartments are separated by a watershed SSW-NNE, passing between the centers of Ain Leuh and Timahdite.

The approximate balance of the Quaternary basalt water table of the Middle Atlas is summarized in the table below.

Table 1. Assessment of Quaternary Basalt Water Resources in the Middle Atlas Causa

\begin{tabular}{|c|c|}
\hline \multicolumn{2}{|c|}{ Inputs (Mm³ /year) } \\
\hline Infiltration of rainwater & 57 \\
\hline Childbirth with the tablecloth of Lias & 20 \\
\hline Return of irrigation water & 9 \\
\hline Total Entries & 86 \\
\hline \multicolumn{2}{|c|}{ Outputs (Mm³/year) } \\
\hline Drainage of sources & 31 à 46 \\
\hline Drainage of wadis Tigrigra and Derboura & 16 \\
\hline Agricultural levies & 15 \\
\hline Rural AEP levies & 2 \\
\hline Total Outputs & 64 à 79 \\
\hline
\end{tabular}

\subsubsection{Aquifer of Middle Lias}

This water table circulates mainly in dolomitic formations (compact, sandy or bedded) of the lower and middle Lias. In the southern section of Causse, the aquifer consists essentially of limestone formations. The accident line of Tizi N'Tretten marks the boundary between the two facies constituting the aquifer of the Middle-Atlas Causse.

Water circulates in cracks, fractures and karst channels. These discontinuities favor the infiltration of rainwater, which is the main source of food for the Liasique aquifer.

The only feeds in the basin are meteoric; the emissions are constituted by the drainage of the waters of Ain Aicha-Hammad ( ${ }^{\circ}$ IRE 49/30), the Wadi Ain-Leuh and the sources Aioun-Akadous and toufstelt.

In the absence of piezometric monitoring of the Aïn Leuh-Azrou basin and large withdrawals from wells and boreholes, the water balance (of this basin) is assumed to be balanced. The drainage flow of Ain Leuh wadi and quaternary basalts (Tioumliline and Tagounite) is estimated (from this assessment) at about $41 \mathrm{Mm}^{3} /$ year $\left(1.3 \mathrm{~m}^{3} / \mathrm{s}\right)$, which is 
of the same order of magnitude than that evaluated by the Sebou Basin Hydraulic Agency (ABHS) in 2003 (Table 2).

Table 2. Assessment of water resources in the basin Lias

\begin{tabular}{|c|c|}
\hline \multicolumn{2}{|l|}{ Inputs ( $\mathrm{Mm}^{3} /$ year) } \\
\hline Infiltration of the rain & 36 \\
\hline Total Entries & 36 \\
\hline \multicolumn{2}{|l|}{ Outputs ( $\mathrm{Mm}^{3} /$ year) } \\
\hline Drainage of sources & 1.7 \\
\hline $\begin{array}{l}\text { Drainage of Ain Leuh wadi and Quaternary basalts } \\
\text { (Tioumliline and Tagounite) }\end{array}$ & $34.3^{(*)}$ \\
\hline Total Outputs & 36 \\
\hline
\end{tabular}

$(*)$ : Derived from the hydraulic balance of the basin.

\subsubsection{Water point data IRE located in the study area}

The study of drilling datasheets showed us that the following $N^{\circ} \operatorname{IRE}$ points (ABHOER), are the most representative for the hydrogeological recognition of the study area:

NoIRE: 1775-22 (Located northwest of the study area).

- Nature: Drilling.

- Situation map: Ain Leuh au $50000^{\text {th }}$.

- Lambert coordinates (in $m$ ) : $X=505600, Y=$ 300600 et $Z=1330$.

- Measurable depth: $150 \mathrm{~m}$.

- $\quad \mathrm{NP} / \mathrm{sol}: 40.98 \mathrm{~m}$.

- Electrical conductivity (at $25^{\circ} \mathrm{C}$ ): 1042 $m h o / c m$.

- Water temperature: $19.4^{\circ} \mathrm{C}$.

- Dry residue at $105^{\circ} \mathrm{C}$ : $729 \mathrm{mg} / \mathrm{l}$.

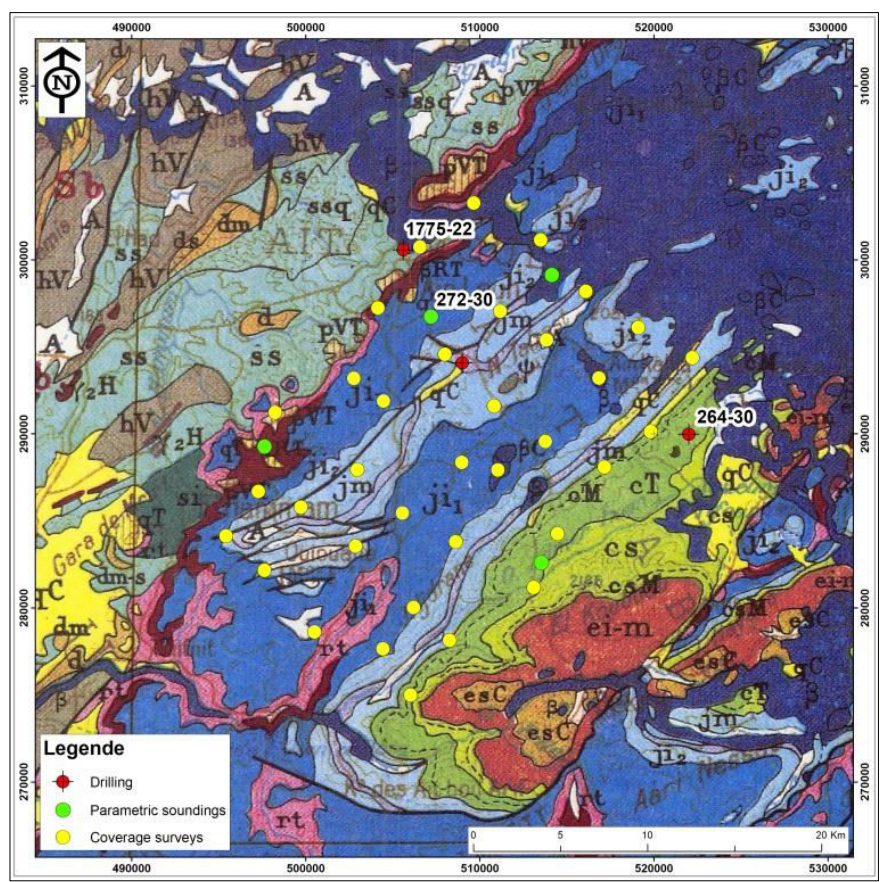

Fig. 2. Geological map of the study area (extracted from the geological map of Morocco at 1: 500,000)

NoIRE : 272-30 (Located west of the study area).

- Nature: Drilling.

- Situation map: Al Hammam au $50000^{\text {th }}$.

- Lambert coordinates (in $\mathrm{m}$ ) : $X=509000, Y=294100$ et $Z=1840$.

- Measurable depth: $130 \mathrm{~m}$.

- NP/sol: $41.20 m$.

- Electrical conductivity (at $25^{\circ} \mathrm{C}$ ): $426 \mathrm{mho} / \mathrm{cm}$. 
- Water temperature: $12.4^{\circ} \mathrm{C}$.

- Dry residue at $105^{\circ} \mathrm{C}$ : $298 \mathrm{mg} / \mathrm{l}$.

N'IRE : 264-30 (Located east of the study area).

- Nature: Drilling.

- Situation

map : Timahdit au $50000^{\text {th }}$.

- Lambert coordinates (in $m$ ) : $X=522000$, $Y=290000$ et $Z=1920$.

- Measurable depth:

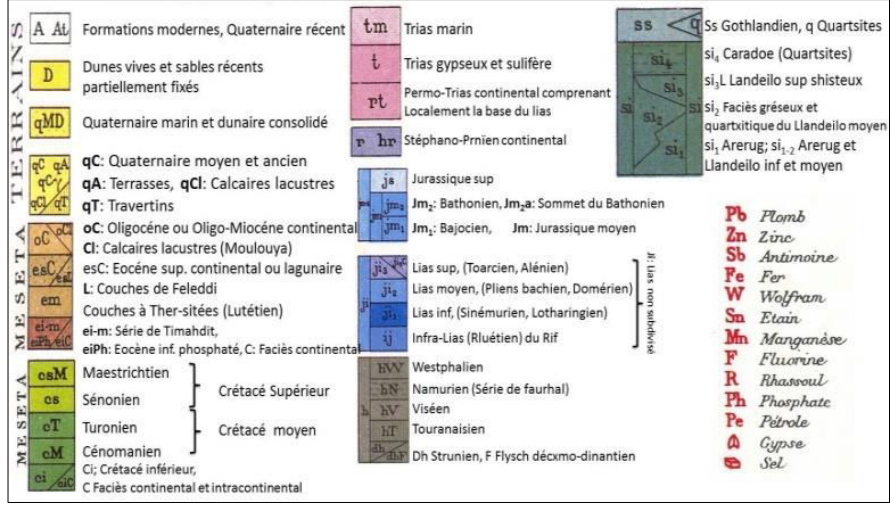

Fig. 3. Legend of the geological map of Morocco at 1/500 000 $160 \mathrm{~m}$.

- NP/sol: $77.07 m$.

- Electrical conductivity (at $25^{\circ} \mathrm{C}$ ): $743 \mathrm{mho} / \mathrm{cm}$.

- Water temperature: $11.1^{\circ} \mathrm{C}$.

- Dry residue at $105^{\circ} \mathrm{C}: 520.1 \mathrm{mg} / \mathrm{l}$.

\section{Materials and methods}

\subsection{Methodology}

\subsubsection{Principle of the ES method (fig. 4)}

The electrical survey allows to study the variation of the resistivity of the soil with the depth [1-9-10-11]. Data acquisition in the field is as follows: A current of intensity (I) is sent through two electrodes $\mathrm{A}$ and $\mathrm{B}$ by means of batteries or a generator. Using a potentiometer (direct reading) or a recorder, the potential difference $(\Delta \mathrm{V})$ between two measurement electrodes $\mathrm{M}$ and $\mathrm{N}$ is measured by increasing the length of line $\mathrm{AB}$ each time. The values of apparent resistivities obtained represent deeper and deeper depths [1-3-5-6-7-9].

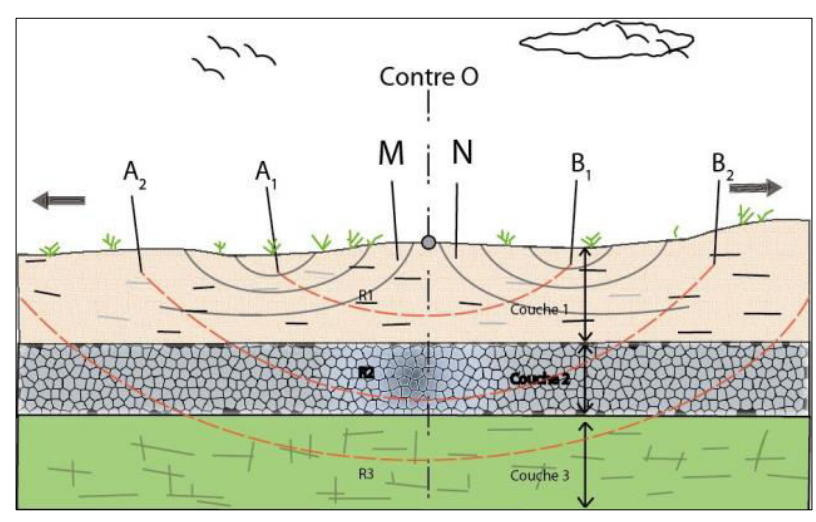

Fig. 4. Schematic diagram of the ES method (Schlumberger device)

The Schlumberger quadrupole, which has been applied in the context of the present study, is characterized by a small distance $\mathrm{MN}$ in front of $\mathrm{AB}$ in order to introduce the notion of electric field thus facilitating the theoretical calculations. The application of the ohm law makes it possible to calculate for each line lenner $\mathrm{AB}$ an apparent resistivity value (R) defined by the following formula [1-9-13]:

$$
R=K . \Delta V / I
$$

$K$ being a coefficient that depends on the AMNB geometry. 


\subsubsection{Processing of ES diagrams}

The electrical sampling diagram (ES) is obtained by plotting on a grid with a bilogarithmic scale the values of $\mathrm{AB} / 2$ (in $\mathrm{m}$ ) on the abscissa and the apparent resistivities (in ohm.m) on the ordinate [1-9-12-13].

The study of these diagrams, their comparison with each other and with abacuses as well as their analysis using computer programs make it possible to determine, in the majority of the cases, the vertical succession of "electric layers" as well as the true resistivity of each. This requires, of course, that the contrasts of resistivities between the different formations are sufficient [1-9-12].

The quantitative interpretation of the electrical soundings conducted in the study area was done on a microcomputer using specific interpretation and processing software. These allow an analysis of smoothed curves with theoretical charts to eliminate the effects of possible taps that could harm the computer analysis [1-5-9-13].

\subsection{Geophysical measurements made}

\subsubsection{Number of surveys}

The geophysical measurements collected in the field were measured by a GRM 3000 resistivity meter. A total of thirty-nine vertical electrical soundings (39 ES) which shows the following distribution (Fig. 5):

- 35 electrical cover surveys carried out on a grid of approximately $4 \mathrm{Km} \times 4 \mathrm{~km}$;

- 4 parametric electrical soundings carried out on the different outcrops of the geological formations.

The 35 coverings were

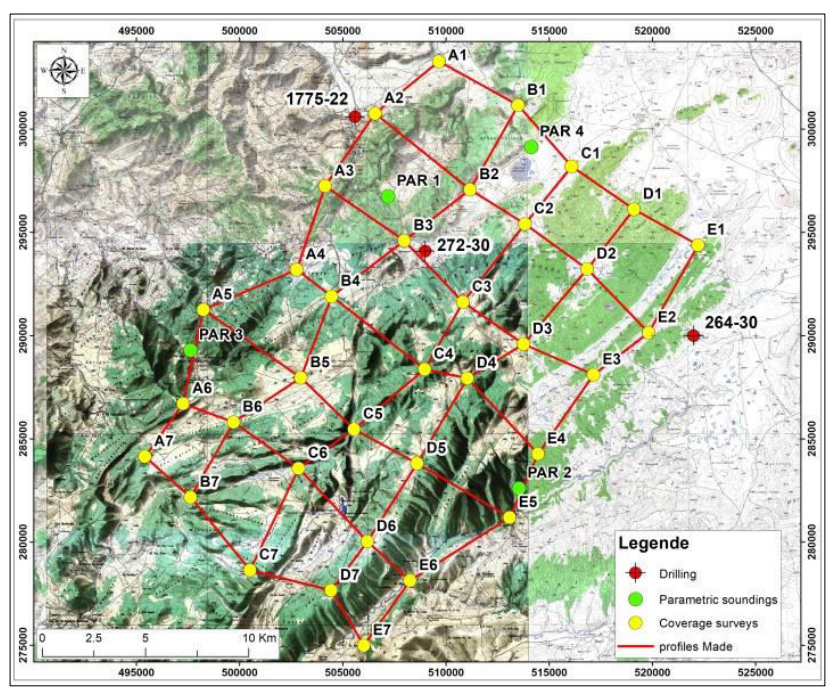

Fig. 5. Situation Map of Electrical Surveys and Geo-Electrical Profiles (Extract of topographic maps of Morocco at 1/50 000) distributed over 7 profiles of 5 electrical soundings according to a $4 \mathrm{Kmx} 4 \mathrm{Km}$ mesh (Table 3).

Ce maillage n'a pas été respecté totalement sur toute la zone d'étude vu les difficultés et les obstacles rencontrés lors de réalisation des mesures électriques sur le terrain (terrain accidenté, clôtures des fermes, oueds...).

Table 3. Distribution of electric soundings by profile

\begin{tabular}{|c|c|}
\hline Profile & Electrical survey \\
\hline Profile A & A1, A2, A3, A4, A5, A6 et A7 \\
\hline Profile B & B1, B2, B3, B4, B5, B6 et B7 \\
\hline Profile C & C1, C2, C3, C4, C5, C6 et C7 \\
\hline Profile D & D1, D2, D3, D4, D5, D6 et D7 \\
\hline Profile E & E1, E2, E3, E4, E5, E6 et E7 \\
\hline
\end{tabular}




\subsubsection{AB line length}

The totality of these electrical soundings was carried out with variable current transmission line lengths $\mathrm{AB}$ ranging up to $3 \mathrm{~km}$ depending on the depth and thickness of the geological formations traversed.

\subsection{Results}

\subsubsection{Electrical soundings diagrams}

The analysis of the diagrams of the electrical soundings made it possible to highlight the existence of a deep resistant substratum noted $\mathrm{Rp}$ and a heterogeneous cover formed of alternation of conductive and resistant grounds.

The comparative study of the lithological layers revealed by the rigging drilling with the horizons detected on the diagrams of the electrical soundings, made it possible to establish geoelectric correlations. The results obtained led to distinguish three main families of electrical soundings (Table 4):

Table 4. Families of electrical soundings

\begin{tabular}{|c|c|}
\hline $\begin{array}{c}\text { Family number of electrical } \\
\text { soundings }\end{array}$ & IRE number of calibration drilling \\
\hline Family 1 & $1775-22$ \\
\hline Family 2 & $272-30$ \\
\hline Family 3 & $264-30$ \\
\hline
\end{tabular}

\section{a) Family 1:}

Table 5 shows the geoelectric characteristics of electrical soundings belonging to this family:

Table 5. Geoelectric characteristics of the family 1

\begin{tabular}{|c|c|c|c|c|}
\cline { 2 - 5 } \multicolumn{1}{c|}{} & $\begin{array}{c}\text { Electrical } \\
\text { levels }\end{array}$ & $\begin{array}{c}\text { Resistivity } \\
(\mathbf{O h m} . \mathbf{m})\end{array}$ & $\begin{array}{c}\text { Thicknesses } \\
(\mathbf{m})\end{array}$ & Geological formation \\
\hline \multirow{2}{*}{$\begin{array}{c}\text { RT level } \\
\text { coverage }\end{array}$} & $\mathbf{R 1}$ & 102 & 10 & $\begin{array}{c}\text { Whitish dolomitic } \\
\text { limestones }\end{array}$ \\
\cline { 2 - 5 } & $\mathbf{C 1}$ & 75 & 24 & $\begin{array}{c}\text { Red clay + sandy } \\
\text { yellow marl }\end{array}$ \\
\hline $\begin{array}{c}\text { RT } \\
\text { Resistant }\end{array}$ & $\mathbf{R T}$ & 1420 & 12 & $\begin{array}{c}\text { Basalts of the Permo- } \\
\text { Triassic }\end{array}$ \\
\hline $\begin{array}{c}\text { Deep } \\
\text { conductor } \\
\text { Cp }\end{array}$ & $\mathbf{C p}$ & 2.5 & 18 & Yellowish Marl \\
\hline $\begin{array}{c}\text { Deep } \\
\text { Resistant } \\
\text { Substrate }\end{array}$ & $\mathbf{R p}$ & 5000 & - & Black shales (Primary) \\
\hline
\end{tabular}

These electrical soundings were carried out on the outcrops of the lower Jurassic carbonate formations (lower Lias). The analysis of the diagram of these electrical soundings made it possible to highlight two deep resistant levels having resistivities of the order of $1420 \mathrm{Ohm} . \mathrm{m}$ and $5000 \mathrm{Ohm} . \mathrm{m}$ (figure 6). 


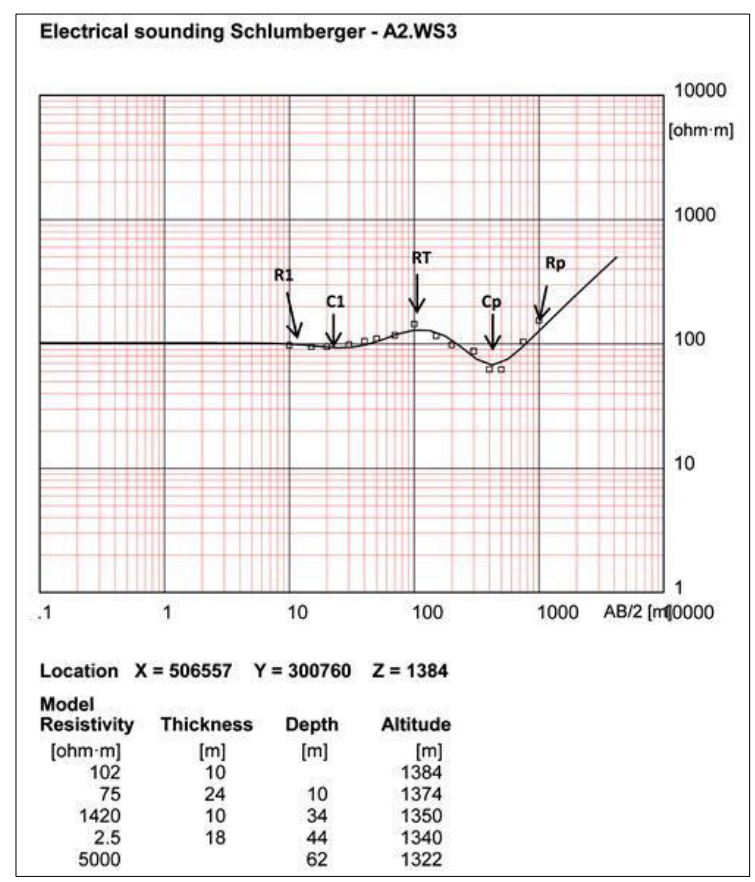

Fig. 6. Electrical resistivity curve of the electrical sounding No.IRE 1775-22.

\section{b) Family 2:}

This family is characterized by the thickening of the level coverage. It consists essentially of alternating conductive and resistant levels of the lower and middle Jurassic whose total thickness is of the order of $150 \mathrm{~m}$ (Table 6).

Table 6. Geoelectric characteristics of the family 2

\begin{tabular}{|c|c|c|c|c|}
\hline & $\begin{array}{c}\begin{array}{c}\text { Electrical } \\
\text { levels }\end{array} \\
\end{array}$ & $\begin{array}{c}\text { Resistivity } \\
\text { (Ohm.m) }\end{array}$ & $\begin{array}{c}\text { Thicknesses } \\
(\mathbf{m})\end{array}$ & Geological formation \\
\hline \multirow{4}{*}{$\begin{array}{l}\text { RT level } \\
\text { coverage }\end{array}$} & R0 & $70-150$ & 26 & \multirow{4}{*}{$\begin{array}{c}\text { Yellowish marl }+ \\
\text { marno-limestone }+ \\
\text { limestone fractured } \\
\text { dolomitic limestone }+ \\
\text { gray marl (lower and } \\
\text { middle lias) }\end{array}$} \\
\hline & Co & 2 & 5 & \\
\hline & R1 & $120-200$ & 20 & \\
\hline & C1 & $35-500$ & 34 & \\
\hline RT Resistant & RT & 1000 & 12 & $\begin{array}{c}\text { Basalts of the Permo- } \\
\text { Triassic }\end{array}$ \\
\hline $\begin{array}{c}\text { Deep } \\
\text { conductor } \mathbf{C p}\end{array}$ & Cp & 50 & 22 & Gray marl \\
\hline $\begin{array}{l}\text { Deep Resistant } \\
\text { Substrate }\end{array}$ & Rp & 2000 & - & Black shale (Primary) \\
\hline
\end{tabular}

The analysis of the diagram of this electrical survey allowed to individualize a succession of electric grounds (RT, Cp and Rp). The deep resistive RT substrate with an electrical resistivity of $2000 \mathrm{Ohm} . \mathrm{m}$ corresponds according to the geology of the region and the lithological cut of the rigging drilling to shale formations of the Primary. The latter is based on a conductive level Cp (50 ohm.m) whose thickness is $22 \mathrm{~m}$.

The set of Rp and Cp lands is surmounted by a resistant level noted RT, the value of the electrical resistivity is of the order of $1000 \mathrm{Ohm} . \mathrm{m}$. This resistant level is attributed to Permo-Trias basalts. 


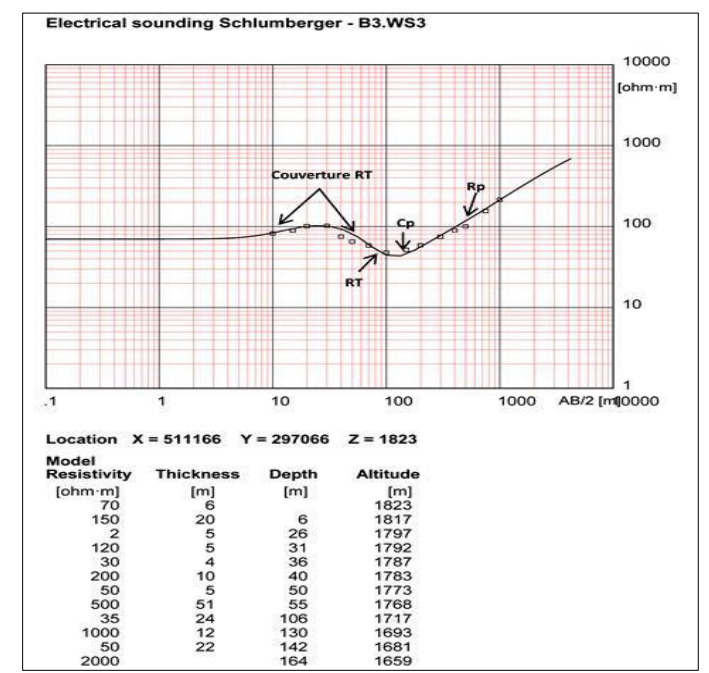

Fig. 7. Electrical resistivity curve of the electrical sounding No.IRE 272-30.

\section{c) Family 3:}

These electrical soundings have the characteristic that they do not show the resistant level RT attributed to basalts of Permo-Trias. The Jurassic cover lies directly on an impervious substratum consisting of triassic clays and marls (Table 7).

Table 7. Geoelectric characteristics of the family3

\begin{tabular}{|c|c|c|c|c|c|}
\hline & & & $\begin{array}{c}\begin{array}{c}\text { Resistivity } \\
\text { (Ohm.m) }\end{array} \\
\end{array}$ & $\begin{array}{c}\text { Thicknesses } \\
(\mathbf{m})\end{array}$ & $\begin{array}{l}\text { Geological } \\
\text { formation }\end{array}$ \\
\hline \multirow{6}{*}{$\begin{array}{l}\text { RT level } \\
\text { coverage }\end{array}$} & \multirow{2}{*}{ R0 } & $\mathbf{c}_{0}$ & $15-62$ & 56 & \multirow{6}{*}{$\begin{array}{c}\text { Yellowish marl + } \\
\text { marno-limestone }+ \\
\text { limestone fracturee } \\
\text { limestone gray } \\
\text { marl plastic + hard } \\
\text { limestone (lower } \\
\text { and middle lias) }\end{array}$} \\
\hline & & $\mathbf{r}_{0}$ & 160 & 31 & \\
\hline & \multicolumn{2}{|c|}{$\mathrm{CO}$} & 18 & 5 & \\
\hline & \multicolumn{2}{|c|}{ R1 } & 100 & 43 & \\
\hline & \multirow{2}{*}{ C1 } & $\mathbf{c}_{1}$ & 4 & 11 & \\
\hline & & $\mathbf{r}_{1}$ & 200 & 7 & \\
\hline $\begin{array}{c}\text { Deep } \\
\text { conductor } \\
\text { Cp }\end{array}$ & \multicolumn{2}{|c|}{ Cp } & 25 & 22 & $\begin{array}{c}\text { Gray marl (Permo- } \\
\text { Triassic) }\end{array}$ \\
\hline $\begin{array}{c}\text { Deep } \\
\text { Resistant } \\
\text { Substrate }\end{array}$ & \multicolumn{2}{|c|}{$\mathbf{R p}$} & 550 & - & Oil Shale (Primary) \\
\hline
\end{tabular}

The interpretation of these electrical soundings and their correlations with the lithological succession given by the corresponding calibration holes made it possible to distinguish (figure 8):

- A deep resistant substrate Rp whose resistivity is equal to $550 \mathrm{ohm}$.m. Its roof is located at a depth of $157 \mathrm{~m}$; and which, according to the description of the drilling, corresponds to oil shale of primary age.

- A conductive level $\mathrm{Cp}$, attributed to gray marls of Permo-Trias whose resistivity value is of the order of $25 \mathrm{Ohm} . \mathrm{m}$.

- A conductive level cover $\mathrm{Cp}$ formed of a succession of conductive and resistant levels. 


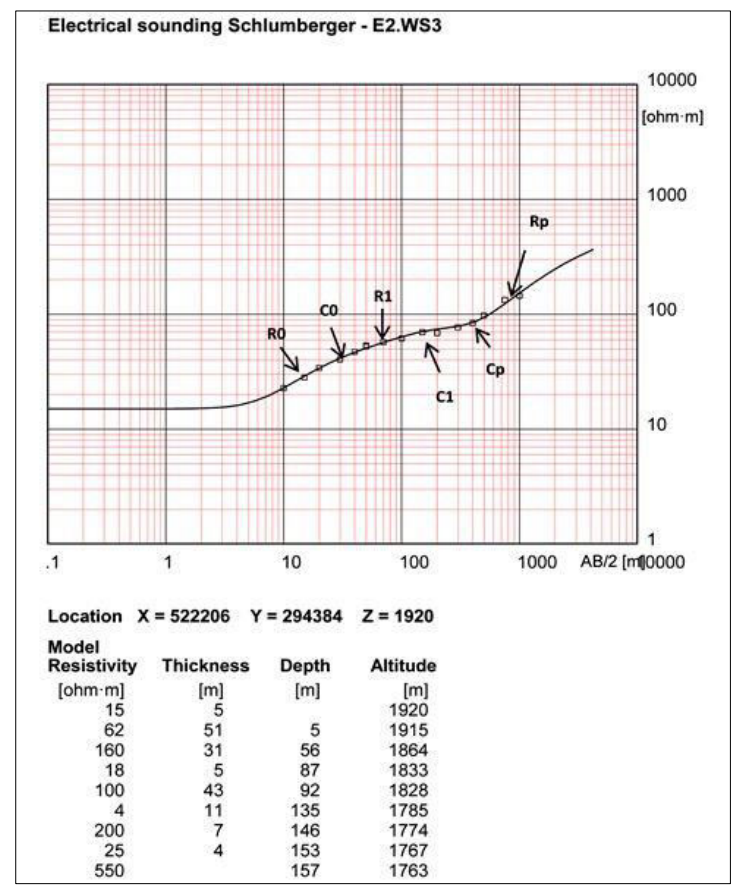

Fig. 8. Electrical resistivity curve of the electrical sounding No.IRE 264-30.

\subsubsection{Geoelectric cuts}

On the one hand, the geoelectric sections make it possible to visualize in a clear manner the structure in depth of the study area and to follow the lateral and vertical variation of the geological formations, and on the other hand to determine the roof and the wall of all formations likely to constitute aquifers.

Two types of geoelectric cutting were carried out as part of this work, the NorthSouth longitudinal crosssections and the West-East cross-sections. In order to better follow in depth the variation of the different electrical levels detected, two longitudinal NE-SW geoelectric cuts and two NW-SE cross sections were

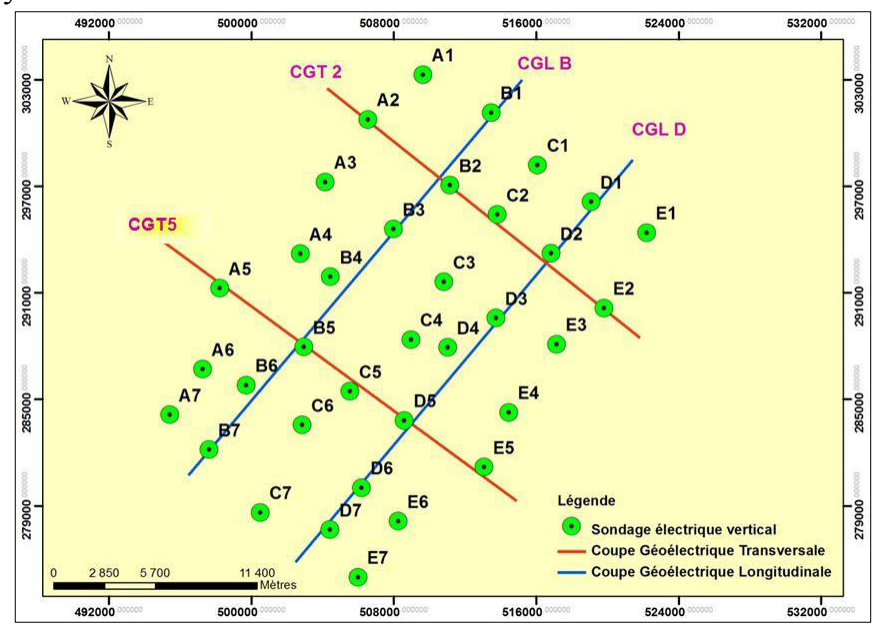

Fig. 9. Plan de situation des coupes géoélectriques. made. (figure 9):

- the longitudinal geoelectric section B comprises the electrical soundings B1, B2, B3, B4, B5, B6 and B7;

- the longitudinal geoelectric section D comprises the electrical soundings D1, D2, D3, D4, D5, D6 and D7;

- the transverse geoelectric section 2 comprises the electrical soundings A2, B2, C2, D2 and E2; 
- the transverse geoelectric section 5 comprises the electrical soundings A5, B5, C5, D5 and E5.

\section{a) Longitudinal geoelectric section $B$ (CGL B)}

This section was made on the outcrops of carbonate formations of Middle Lias (Middle Jurassic) over a length of about $25 \mathrm{Km}$ (figure 10).

The analysis of the geoelectric section shows the following information:

- The roof of the aquifer levels (R0, R1, RT and Rp) shows a wave structure over the entire section.

- The deep resistant substratum noted $\mathrm{Rp}$ attributed to Paleozoic schistose formations is surmounted by a conductive level (Permo-Triassic clay loams), whose thickness varies between $18 \mathrm{~m}$ and $25 \mathrm{~m}$, and its resistivity oscillates between $30 \mathrm{Ohm} . \mathrm{m}$ and 55 Ohm.m.

- The roof of the four aquifer levels shows a deepening from the B3 electrical survey towards the South-West.

- Lower Lias aquifer in calcare

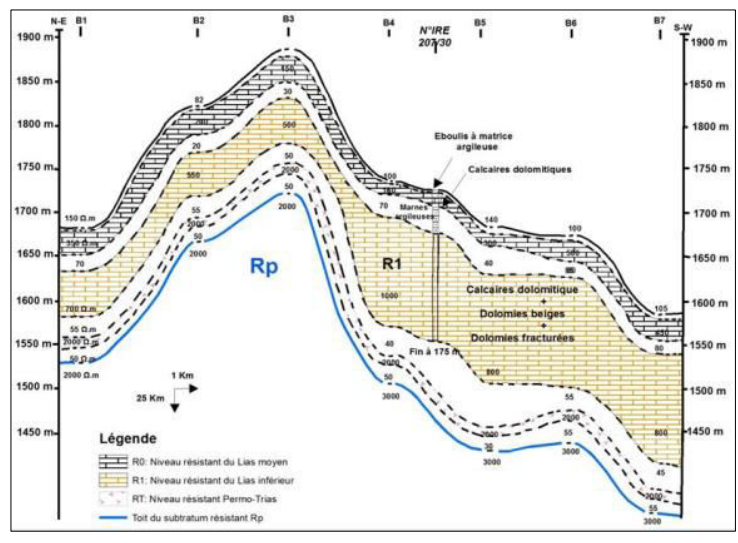

Fig. 10. Longitudinal geoelectric section B. dolomitic formations (noted R1) shows deepening and thickening to the southwest.

b) Transverse geoelectric section 2 (CGT 2)

This cut was made in the south of the study area over a length of about $17 \mathrm{~km}$. It crosses the outcrops of the lower and middle Lias (figure 11).

The analysis of this section made it possible to deduce the following information:

- Resistant level R1 outcrops to the northwest. It shows a significant burial in the electrical sounding A2.sa electrical resistivity varies between 100 Ohm.m and 300 Ohm.m ;

- The roof of the resistant

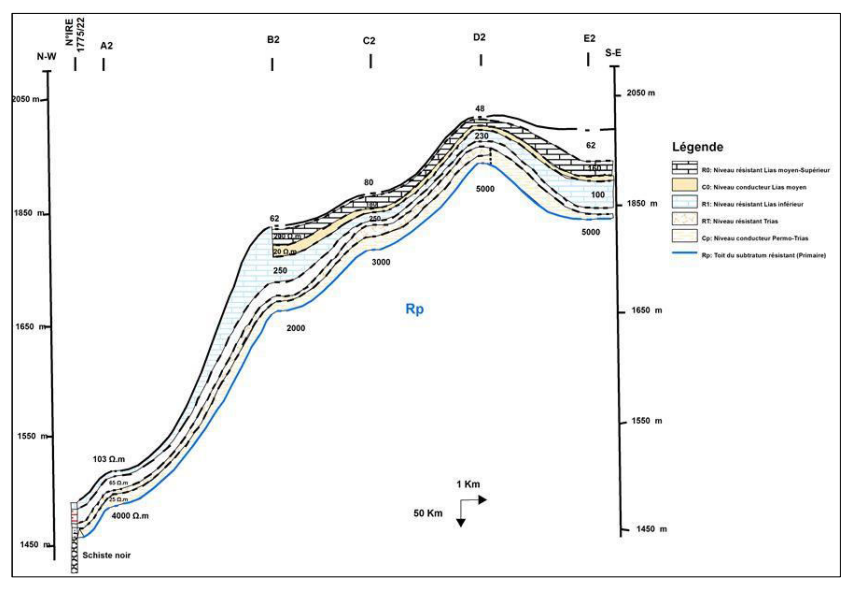

Fig. 11. Transverse geoelectric section 2 . bedrock Rp shows a progressive burial going from the South-East towards the NorthWest towards the outcrops of the Lower Lias where the depth of its roof is of the order of $64 \mathrm{~m}$;

- An electrical discontinuity at the contact of the RT level and the deep conductor level noted $\mathrm{Cp}$ was highlighted. This discontinuity could also be interpreted in terms of fault. 


\subsubsection{Geoelectric maps}

The isopach maps are based on the thickness values of the main aquifer levels recorded on the geoelectric sections: the resistant levels R0; R1 and RT.

This map (figure 12) tracks the variation of the first level aquifer power R0 attributed to fractured carbonated and dolomitic lands of the middle and upper Lias.

The analysis of this map makes it possible to distinguish:

- A shallow area located northeast and southwest of the study area;

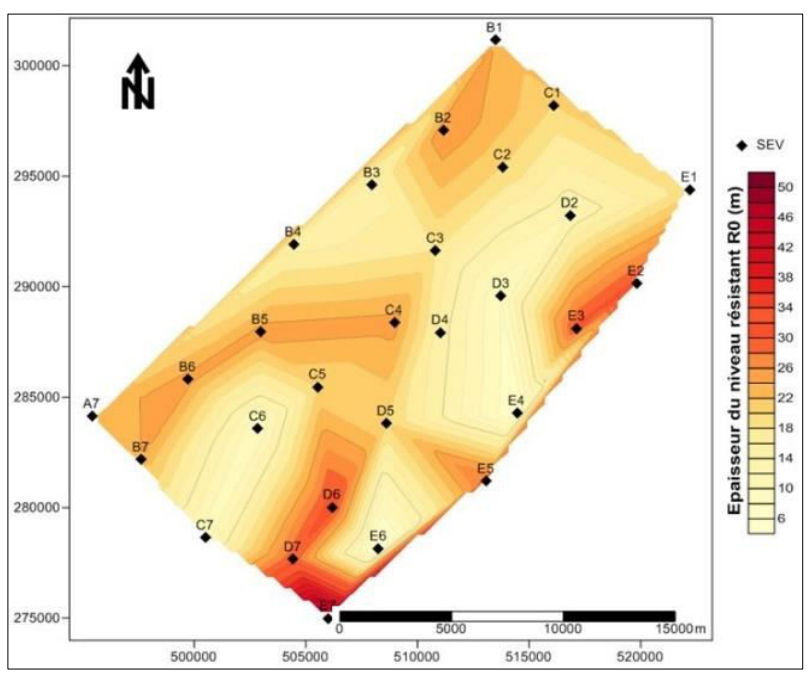

Fig. 12. Isopach map of resistant level R0.

- An area of high thickness values located mainly in the extreme south of the study area where the thickness has a maximum value of $52 \mathrm{~m}$.

The isopach map of aquifer level R1 (figure 13) shows that the thickness of this level varies between $10 \mathrm{~m}$ and $110 \mathrm{~m}$.

Examination of this map made it possible to distinguish:

- A high-power area, located at the northeastern and southwestern end of the study area.

- A low to medium area in the northern and central parts of the study area.

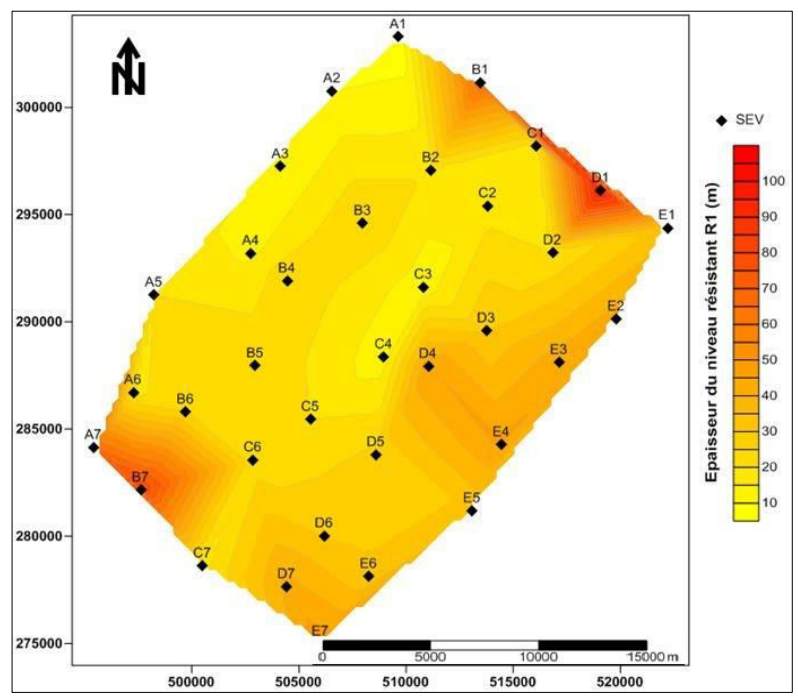

Fig. 13. Isopach map of the resistant level R1 
Examination of this map shows that the ranges of the thickness values of this aquifer level RT oscillate between $6 \mathrm{~m}$ and more than $56 \mathrm{~m}$. The maximum thickness of this reservoir is observed at the southwestern end of the study area, while the low thicknesses (thickness $\leq 22 \mathrm{~m}$ ) are distributed north and west of the study area.(figure 14).

Overall, aquifer level R1 shows a thick zone located in the southwest and a thin zone located northeast of the study

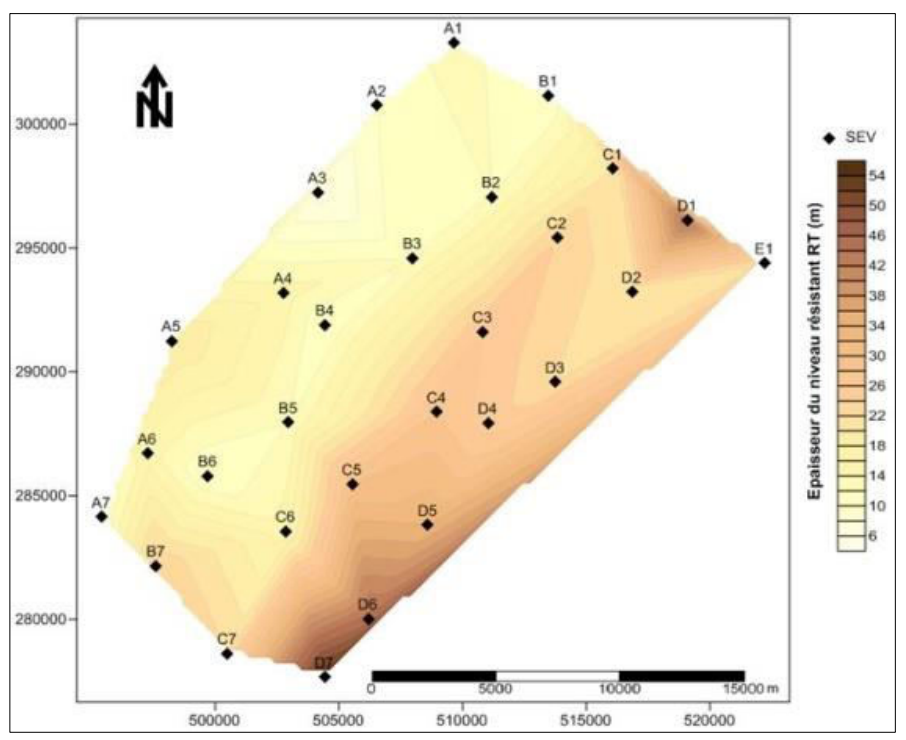

Fig. 14. Carte des isopaches du niveau résistant RT area.

The isohypse maps were developed from the roof elevation values of the aquifer levels found on the geoelectric sections (R0, R1, RT and $\mathrm{Rp})$.

This map is based on the values of the aquiferlevel wall coast recorded on geoelectric sections (Figure 15).

Examination of this map allowed showing:

- that the roof moves progressively from the northwest to the southeast of the study area;

- that the high altitude values of the roof recorded in the south-east of the

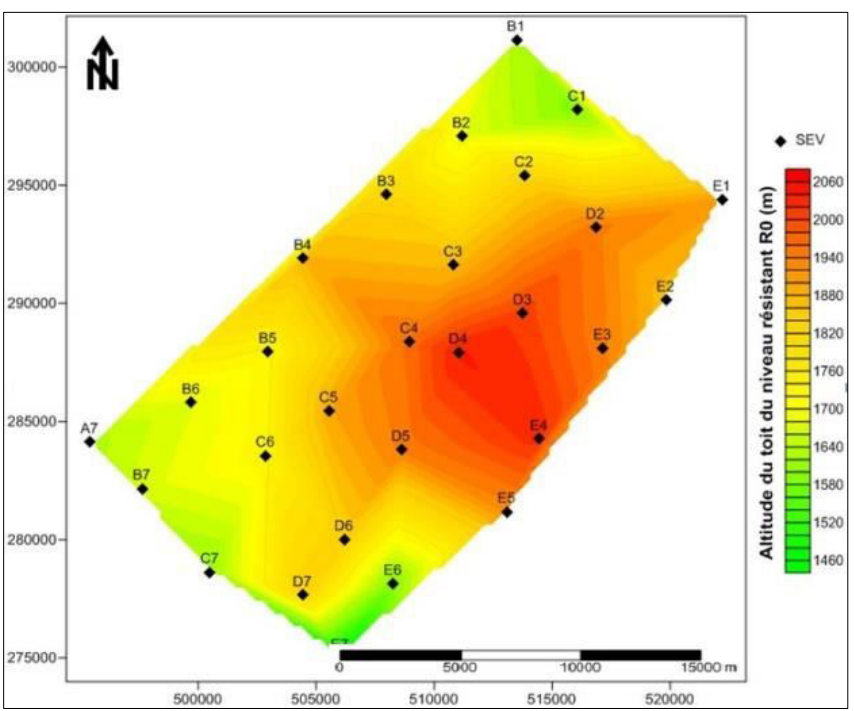

Fig. 15. R0 aquifer roof roof isohypsis map study area reflect the raising of the roof of this level towards the surface at this location;

- a rise of the roof of this aquifer R0 towards the South-East in the direction of the outcrops of dolomitic-limestone formations of Lias medium-superior. 
The following map shows that the roof of this aquifer level varies from $1350 \mathrm{~m}$ and more than $2050 \mathrm{~m}$. This resistant level corresponds according to the geoelectric correlation with limestone and dolomitic formations of the lower Lias. The analysis of this map (figure 16) shows:

- That the high altitude values are recorded in the north-west of the study area while the low values are observed in the southeast of the study area ;

- The roof of this aquifer level shows a rise from

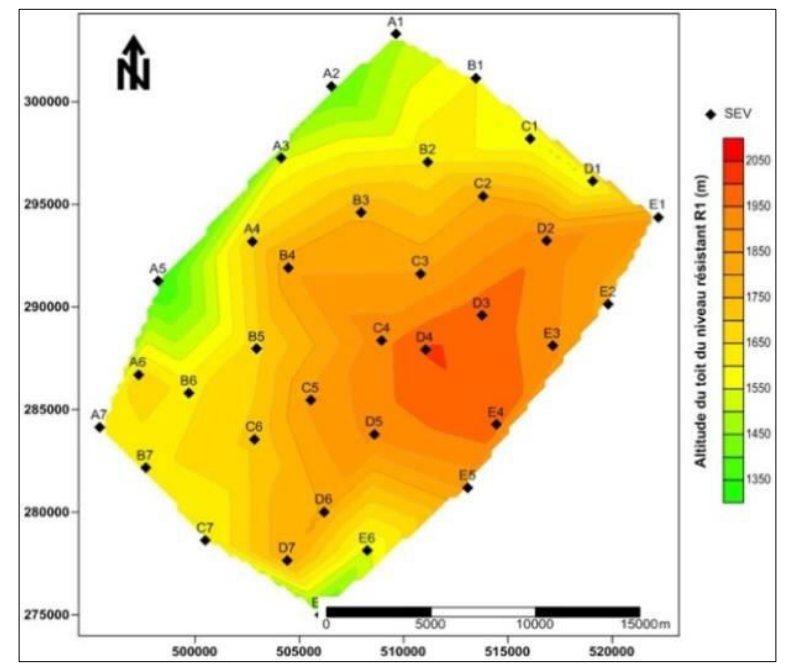

Fig. 16. Map of the isohypse of the roof of aquifer level R1 north-west to south-east of the study area ;

- The high values recorded in the South-East reflect the rising of the roof of this aquifer level in these places.

This map (Figure 17) is based on the values of the roof coast of the aquifer level RT recorded on the geoelectric sections. Examination of the map of the map made it possible to highlight:

- A low elevation area $(\leq 1600)$, located in the northwestern part of the study area ;

- An area located in the south-east of the study area, where the roof of the aquifer reaches more than 1950 m altitude;

- The roof of this aquifer level RT is gradually rising towards the south-east of the study area.

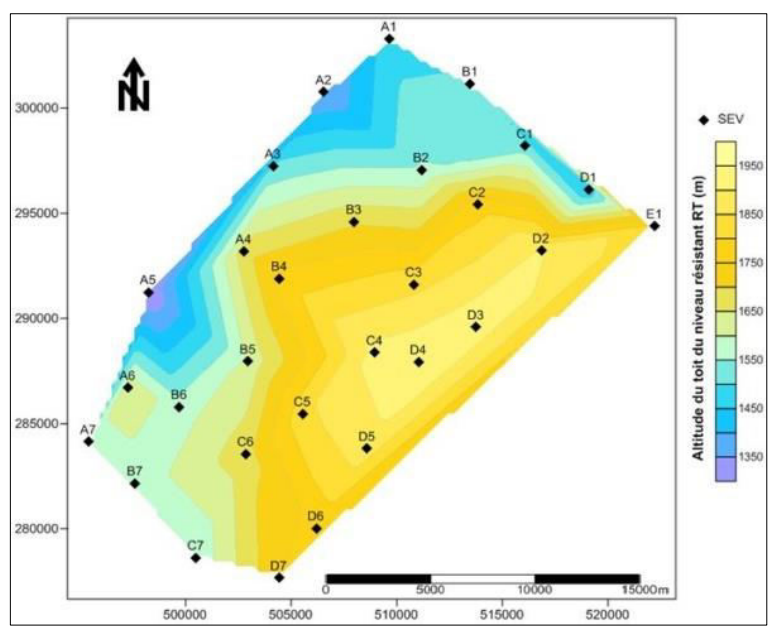

Fig. 17. Map of the isohypse of the roof of resistance level 
The following map shows the elevation variation of the roof of the Rp resistant bedrock attributed to Paleozoic black shale. This variation extends from $1300 \mathrm{~m}$ to a maximum value of $2000 \mathrm{~m}$ (figure 18).

Areas of low altitude are observed south-west of the study area, these areas correspond to areas where the roof of the resistant bedrock is close to the surface, ie they correspond to the low-power areas of the area blanket.

Overall, the resistant level Rp shows a progressive

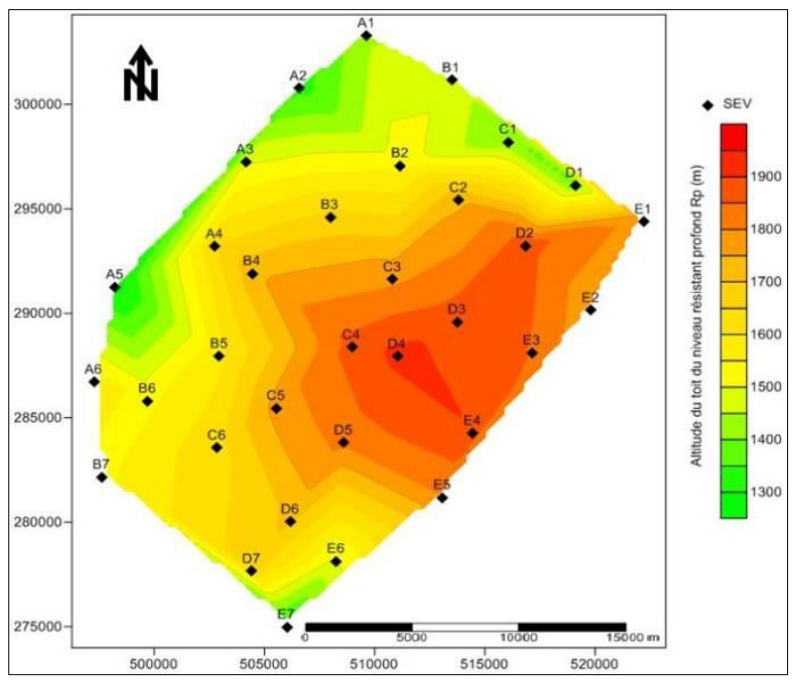

Fig. 18. Map of the isohypse of the Rp aquifer level deepening from the North-West to the South-East of the study area.

It appears from the analysis of the results obtained that:

$>$ For the aquifer level of the lower-middle Lias (the first two potentially aquiferous levels R0 and R1 forming the deep-bedrock cover) :

$\Rightarrow$ The aquifer-level roof of the Lias shows a wave structure that rises to the southeast of the study area.

$\Rightarrow$ This aquifer level shows a thickening towards the south-east of the study area, in the direction of the outcrops of the limestone and dolomitic formations generally fractured of Lias inferior-average.

$\Rightarrow$ These outcrop zones constitute the natural recharge zones of this layer.

$\Rightarrow$ Cracking and karstification of limestone formations forming this aquifer favoring the infiltration and circulation of rainwater and subsequently its feeding.

For the RT aquifer level:

$\Rightarrow$ This second aquifer level corresponds to altered basalts Permo-Trias.il shows a thickening towards the South-East of the study area where its power holds a maximum value of $60 \mathrm{~m}$.

$\Rightarrow$ The roof of this level has a wave structure that plunges to the northwest of the study area.

For the RP aquifer level:

$\Rightarrow$ This deep aquifer level, attributed to Paleozoic schistose formations.

$\Rightarrow$ This resistant substratum shows a progressive deepening from the North-West to the South-East of the study area (towards the Lias and Turonian outcrops).

\section{Conclusions}

The electrical resistivity method applied to the recognition of underground aquifers is a method that can be adapted to both regional and local studies. In fact, in the regional case, it makes it possible to follow the evolution of petro-physical, geometrical characteristics, etc. in addition to the fact that it allows to locate the areas with potential in waters. In the case 
of local prospecting, it allows at least to define the vertical succession of existing aquifers in addition to the local petrophysical characteristics that can be compared with those of the closest rigging holes.

The comparison of drilling data with the different geophysical surveys carried out on our study area makes it possible to draw the following conclusions:

- Reveal the existence of four resistant electric horizons R0; R1; R2; RT and Rp.

- Define the geometry of these aquifer levels by drawing the isopach maps ;

- Follow laterally and vertically the structure and extension of these aquifer levels.

- To monitor the importance and hydrogeological productivity of these aquifer levels by mapping their transverse resistance RT.

Thus, we confirm by our results that the electrical resistivity method is an important guide for the recognition of underground aquifers and for the implantation of mechanical soundings of recognition by increasing their chance of success and thus minimizing the cost of recognition.

\section{5 acknowledgments}

We thank the management of the Oum Er-Rbia Hydraulic Basin Agency for providing us with the data used in this article as well as for their help and constructive suggestions. We also thank all those who contributed directly or indirectly to the development of this work.

\section{References and notes}

1. ASTIER J.L. Géophysique appliquée à l'Hydrogéologie. Masson et Cie, Editeurs, Paris, 1971.

2. Abderahmane BENTAYEB et Claude LECLERC, Le causse moyen atlasique. Ressource en eau du Maroc, Tome 3 : Moyen Atlas et Causse, 1977.

3. BOUKDIR A., Etude hydrogéologique en vue d'une modélisation du système aquifère du Tadla-Plateau des phosphates. CEA, Fac. Scien. Semlalia Marrakech, 1990.

4. BOUKDIR A., Etude géothermique du bassin du Tadla-Plateau des phosphates. DES, Fac. Scien. Semlalia Marrakech, 1994

5. BOUKDIR A. et Al, Prospection des eaux souterraines par méthode des résistivités électriquesApproche méthodologique et etude de cas dans le bassin de l'Oum Er R'Bia. Rencontre national des géomorphologues marocains, Faculté des Lettres et sciences humaines, Béni Mellal, Maroc, 2002.

6. DRPE, Etude par sondages électriques - plaine de Tadla. GEOATLAS SA, 1992.

7. DOBRIN M.B., Introduction to geophysical prospecting. 3rd ed.: New York, Mc Graw Hill Book Co., Inc, 1976.

8. LAGABRIELLE R., TEILHAUD S., Prospection de gisements alluvionnaires en site aquatique par profils continus de résistivité au fond de l'eau, 1981, Bull. liaison labo. P. et Ch. 114:17-24.

9. MEYER DE STADELHOFEN C., Application de la géophysique aux recherches d'eau. Tec. \& Doc. Lavoisier, Paris, 1991.

10. TELFORD W.M., GELDARD L.P., SHERIFF R.E., KEYS D.A., Applied geophysics. New York, Cambridge University Press, 1976

11. MECHLER P., Les méthodes de géophysique. Dunod, Bordas, Paris, 1982.

12. ZHODY A. A. R., A new method for the interpretation of schlumberger and wenner curves, 1989, géophysics, vol. 54, pp. 249-253.

13. G Marquis. Prospection électrique. 2005,5-11.

14. Berengere Charnay, Pour une gestion intégrée des ressources en eau sur un territoire de montagne. Le cas du bassin versant du Giffre (Haute-Savoie). 2010 pp 18.

15. MARTIN J. - Le Moyen Atlas central étude géomorphologique. Notes et Mémoires du Service géologique, $1981,1-447$. 
16. BAALI A. Genèse et évolution au Plio-Quaternaire de deux bassins intramontagneux en domaine carbonaté méditerranéen. Les bassins versants des dayets Afourgagh et Agoulmam (Moyen Atlas, Maroc). Thèse d'État, Université Sidi Mohamed Ben Abdellah, Fès, 1998.

17. Gentil, 1916 ; Russo, 1939 ; Termier, 1936; Dubar, 1954 ; Golo, 1961 